\title{
Congress and Varmus in clash over 'fllegal' embryo research
}

[WASHINGTON] Harold Varmus, the director of the US National Institutes of Health (NIH), came under heavy fire from a congressional subcommittee last week because of lapses that had allowed an NIH-funded researcher to conduct human embryo research in alleged contravention of US law.

"It appears that some in NIH believe they are above the law. They are wrong," said Joe Barton (Republican, Texas), chairman of the oversight and investigations subcommittee of the House of Representatives Commerce Committee, which oversees management of NIH. Barton accused NIH of "lax oversight, miscommunication and an utter lack of sensitivity to the social and moral issues involved".

But Varmus, the only witness at the hearing, said that "We too have a very large respect for law... This episode was highly unusual and unlikely to recur".

The hearing focused on the case of Mark Hughes, a reproductive biologist with whom NIH severed its relationship last autumn on finding that he had breached a congressional ban on federal funding for human embryo research (see Nature 385, 190; 1997).

Hughes is a specialist in single-cell genetic analysis, which can be applied both to nonembryonic cells, such as cancer cells, and to early-stage embryos. DNA from 8-cell embryos produced at in vitro fertilization (IVF) clinics is analysed and, if it is found to be abnormal, the embryos are not implanted. This technique is called preimplantation genetic diagnosis (PGD).

Hughes, who did not testify at the hearing, said in a subsequent statement that he had felt that the federal ban did not to apply to his work, because he was working with DNA from embryos, not the embryos themselves.

"I studied and tested only DNA samples obtained from embryos by technicians at non-NIH funded programs at clinics and universities around the country," he said in a written statement. "It was my belief that this in no way violated any prohibitions against government-sponsored embryo research." The statement adds: "Many people at NIH... knew of my single cell work. I think this demonstrates that I believed, in good faith, that I was permitted to continue my PGD research."

Varmus maintained at the hearing that NIH recruited Hughes in 1994 only to do nonembryonic work, unless an NIH policy then in place forbidding embryo research was changed. He said NIH believed that Hughes was doing embryo research only in his own time and with his own resources, at a separate facility, while doing non-embryonic work at the National Center for Human Genome Research (NCHGR, now the National Human Genome Research Institute (NHGRI)), to which he was recruited by NIH from Baylor University in Houston, Texas. Varmus said that Hughes was repeatedly told of existing prohibitions on embryo research. "He knew what the rules were," Varmus said.

But the politicians produced NIH documents that appeared to contradict Varmus. For instance, the agreement Hughes signed with NCHGR in 1994 states, "pre-implantation genetic diagnosis will also be provided by blastomere biopsy and single-cell [polymerase chain reaction] technology". And an NCHGR publicity book outlining the work of its lead researchers describes Hughes' work as including "genetic diagnosis of the 8-cell preimplantation embryo in vitro".

\section{US attacks EU gene-food labelling move}

[PARIS] The United States last week attacked European Commission proposals to label genetically modified foods saying they are contrary to free trade (see Nature 384, 502; 1997). Raising the prospect of a trade war, Dan Glickman, the US secretary for agriculture, said that America would "not tolerate" segregration of modified bulk products - such as maize - from their traditional counterparts, which he described as impracticable.

This hard line reflects that of the World Trade Organization (WTO), which has ruled that countries cannot refuse imports or require labelling unless they can either show that the product does not meet international standards or produce scientific evidence of risk (see Nature 384, 301; 1996). "Sound science must trump passion," declared Glickman, who argued that genetically modified foods are safe.

The US position could, if not modified, make a trade war inevitable. The 'mad cow' crisis has made European consumers suspicious of scientific reassurances about safety. As a result, Europe is likely to face up to any US challenge at the WTO. Even if the United States won its case, it would probably face a backlash from consumers and retailers against US goods.

The commission adopted the labelling proposal as a directive last week, and it should become law in the European Union by the end of July.

\section{IMAGE \\ UNAVAILABLE FOR COPYRIGHT REASONS}

Hot seat: Varmus (left), seen here at an earlier hearing on cloning, says events surrounding the controversial research are "unlikely to recur".

Varmus told the politicians that the book was "without any obvious implication that that research was being done at the NIH". He added that, when Hughes was hired, NIH had a "reasonable expectation" that the existing prohibition on human embryo research would soon be lifted. The documents simply reflected that expectation. But Ron Klink (Democrat, Pennsylvania), the senior subcommittee Democrat, declared, "We are very troubled by this. It appears to be considering something" that was forbidden. He demanded that Varmus produce earlier communications to Hughes proving that "there was not a wink and a nod" when Hughes was hired.

The congressmen also distributed a recent report by an internal NIH inquiry committee on protection of human subjects. It concluded that preimplantation diagnosis "was a prominent feature of Dr Hughes' activities, as well as those of at least two [NIH-supported postdoctoral fellows] and one Visiting Fellow throughout their association with NHGRI".

The report says that at least one case of preimplantation diagnosis was handled on the NIH campus. It adds that "the work of the Hughes laboratory was presented at in-house NHGRI research retreat days and in the published abstracts of the American Society of Human Genetics in 1995 and 1996. Thus, it appears to the committee that the research activities of the Hughes laboratory were conducted and communicated in an open manner within the NHGRI and general genetics communities."

The federal law pertaining to Hughes' particular embryo work was clear from January last year, when Congress banned federal funding for research on spare embryos from IVF clinics in which embryos are harmed or destroyed.

But when Hughes was hired in 1994, a legal obstacle to federally funded human embryo 
research had recentlybeen lifted, and NIH was operating, according to Varmus's testimony, with the expectation of revising its own policy to reflect this and allow some embryo research. An NIH expert panel - which included Hughes - concluded in December 1994 that federally funded human embryo research was allowable in certain carefully controlled conditions.

While President Clinton immediately blocked an NIH panel recommendation that some creation of human embryos for research purposes be allowed, his order did not address work on 'spare' IVF embryos. This was banned thirteen months later by Congress.

A document provided by NIH but not produced by the congressmen at the hearing supports NIH's version of events. Jeffrey Trent, the scientific director at NCHGR, wrote to a colleague in August 1995 that he had talked to Hughes about his non-NIH embryonic work at nearby Suburban Hospital. "I told [Hughes] that I am not willing to place federal personnel, etc., at Suburban within an IVF facility," Trent wrote.

The NIH also provided letters from Hughes assuring NIH that he was not using NIHfunded staff or equipment at Suburban Hospital - statements later shown to be false, according to an NIH investigation.

At the hearing, Klink also asked Varmus about "all these postdocs that were doing the same thing (that is, preimplantation genetic diagnosis) under Hughes". Did they not "give a damn", he demanded, or were they "intimidated" by Hughes? "I am concerned about a deficiency in mentorship" by Hughes, Varmus responded.

The charge that Hughes intimidated his postdocs into doing work they suspected might be illegal is contained in notes made by Kate Berg, an NIH official, when NIH investigated Hughes in October last year. But Scott Gant, a lawyer representing Hughes, said that Hughes "denies having intimidated anybody."

The NIH human subjects inquiry committee also concluded that Hughes conducted the embryo work at $\mathrm{NIH}$ without the required approval of an NIH ethics board, and without meeting the standards for commercial diagnostic laboratories required by law.

Varmus said that NIH was taking corrective actions to reduce the risk of a recurrence, including ensuring that no other similar research was being conducted, and contacting researchers most likely to stray into the area banned by law.

Other management gaffes surfaced during the hearing. The congressmen grilled Varmus about how Hughes was allowed to load a lorry with more than \$1-million-worth of NIH equipment, including some boxes marked "Suburban Hospital" - on loan to Georgetown University - and leave NIH with it, without a completed loan agreement or inventory. Some of the equipment was diverted to Suburban Hospital.

\section{NIH may drop special funds for 'new investigators'}

[WASHINGTON] Officials at the US National Institutes of Health (NIH) are expected to decide next week whether to eliminate a category of grants for new investigators worth on average $\$ 70,000$ a year for five years about half the standard NIH grants.

The abolition of the grants, known as R29s or First Independent Research Support and Transition (FIRST) awards, has been proposed by an NIH working group on new investigators. The working group was cochaired by Marvin Cassman, director of the National Institute of General Medical Science, and Elvera Ehrenfeld, director of NIH's Division of Research Grants. It was set up last October in response to concern about the impact of tightening NIH funds on young scientists forced to compete against seasoned researchers.

Its report, which is due to be discussed by the directors of NIH institutes on 3 July, recommends that $\mathrm{R} 29$ applicants should in future be required to apply for standard NIH grants (R01s), for which competition is fiercer. But their applications would explain that they were from young scientists who were first-time applicants.

Peer reviewers would be told to accept less preliminary information in such applications than they would from established investigators. And grants to new investigators would generally be made for five years; standard grants usually last three years.

Anne Thomas, a spokeswoman for Harold Varmus, the director of NIH, said that approval of the proposal is not a forgone conclusion and that the discussion at the meeting is expected to be substantive.

The working group argues that R29s deliver too little money to make up for the relative advantage to young scientists of applying in a less competitive pool. (In 1995, R29 applicants had a 28.5 per cent chance of winning an award, as against an 18.2 per cent chance for first-time R01 applicants.)

According to the draft report, the relatively small size of R29 awards has grown "increasingly onerous" for recipients, most of whom are forced to seek supplementary funding. "It seems curious that we accept so easily much smaller awards to new investigators who are likely to be less well equipped to deal with such constraints," says the report.

It also points out that those awarded R29 grants are consistently less successful in subsequent grant applications than new investigators whose first grant is a standard one.

The draft report concedes that, while the suggested changes would ensure more money for successful young scientists, "there is clearly a concern that success rates will

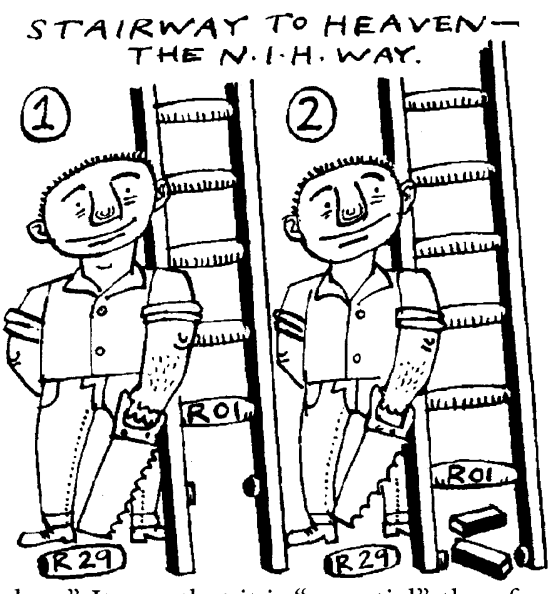

drop". It says that it is "essential", therefore, for the NIH to define a desired entry rate for new investigators, and to ensure that this is at least sufficiently high to replace those retiring, about 9 per cent per year.

Ehrenfeld points out that the data analysed by the working group, for the years 1980 to 1995 , show that younger scientists are not being selectively disadvantaged by dwindling research dollars. Although grant application success rates have gone down, "they've gone down for everybody", she says. New investigators "are faring as well as anybody else."

The report shows that the success rate for new R01 applicants dropped from 26.2 per cent in 1980 to 18.2 per cent in 1995 , while the rate for experienced investigators dropped from 30.5 to 22.5 per cent.

Some scientists are concerned about the possible impact of the changes. John Moore, of the Aaron Diamond AIDS Research Center in New York, says that the impact of R29 awards in his own laboratory has been helpful. He says that the working group has addressed "the critical issue" that a young investigator cannot generate the same amount of preliminary data as an established scientist.

But, reacting to the proposal that new applicants should be judged differently for R01 applications based on identifying information, Moore, a veteran of NIH study sections, says he would ask "would study sections pay much attention to that?"

Others, such as Jais Lingappa, a cell biologist and R29 grant applicant at the University of California, San Francisco, are worried that the changes could mean that fewer young scientists will win funding. But she praises the idea of granting newcomers larger awards, provided they are made for five years. "What the young investigator really needs is three or four years of protected time," she says. 